\title{
Bile Duct Biliary Intraepithelial Neoplasia
}

National Cancer Institute

\section{Source}

National Cancer Institute. Bile Duct Biliary Intraepithelial Neoplasia. NCI Thesaurus. Code C96945.

A neoplastic, non-invasive lesion that affects the intrahepatic or extrahepatic bile duct epithelium. It is characterized by the presence of atypical epithelial cells with an increased nuclear/cytoplasmic ratio, nuclear hyperchromasia, and loss of nuclear polarity. 